\title{
Affectus \& Intellectus: A Medieval Point of View
}

\author{
Peter Nickl \\ University of Regensburg
}

\begin{abstract}
To put the ongoing debate in the philosophy of emotions in a wider context, access to medieval philosophy could turn out to be useful. Huxley's "Brave New World” is a world without history and without strong emotions—so let's plea for both. The medieval complementarity of intellectus and affectus is an example of the central role of the emotive powers in medieval anthropology. It could be worth discussing even today, as well as the notion of scientia affectiva. By the way, a Franciscan thinker of the 13th century, Olivi, seems to explain better than Descartes the depths of subjectivity: I think, therefore I am—but I feel, therefore I am I.

Keywords: affectus, intellectus, subjectivity in medieval philosophy, scientia affectiva
\end{abstract}

\section{No Feelings (Huxley’s “Brave New World”)}

To begin, let me remind you of Aldous Huxley’s Brave New World, a book written in 1932 that anticipates so much of present day reality.

In order to have a world without pain, a world of scientific progress on the one hand, and of pleasure on the other hand, two things have to be abolished: history and strong feelings.

"History is bunk," is one of the famous sayings of Ford, the pseudo-religious authority of the Brave New World. Do you remember the scene where the Controller explains what the abolition of history means?

"He waved his hand; and it was as though, with an invisible feather whisk, he had brushed away a little dust, and the dust was... Job... Jupiter and Gotama and Jesus. Whisk... the cathedrals; whisk, whisk, King Lear and the Thoughts of Pascal. Whisk, Passion; whisk, Requiem; whisk, Symphony...” (Aldous Huxley 1994, 30).

Strong feelings don't fit into the Brave New World, either. Or, to put it in the Controller's words: "Fortunate boys! ... No pains have been spared to make your lives emotionally easy — to preserve you, so far as that is possible, from having emotions at all” (Aldous Huxley 1994, 39).

Ironically, there is a "College of Emotional Engineering” (Huxley 1994, 141), which studies emotions in order to control them and to keep them in somehow infantile limits.

Huxley's message is clear: A civilization which looks exclusively into the future, which relies only on technical solutions of human affairs, which bans history and calms down disturbing emotions, destroys mankind.

\section{A Plea for Medieval Philosophy}

I am deeply convinced that knowledge about man doesn’t begin with modern science. Or, to put it in other

Peter Nickl, Prof., Dr., Institute of Philosophy, University of Regensburg, Germany; main research field: Moral Philosophy, Medieval Philosophy, and Philosophical Anthropology. Email: peter.nickl@phil.uni-hannover.de.

Paper presented at the 2nd annual conference of The European Philosophical Society for the Study of Emotions in Edinburgh, 15 July 2015. 
words: Our fathers and grandfathers, former generations who were far removed from our level of scientific and technical progress, nevertheless knew the essentials about human life, about morals, about happiness and values. It would be absolutely destructive to deny the status of "men" to people who lived 50, or 100, or 1000 years before us, only because the state of scientific progress was, seemingly, ridiculous compared to ours.

If you enter St. Giles' Cathedral in Edinburgh, which dates from the 15th century, would you deny a true sense of beauty to those who built it? Just as Gothic buildings speak to us because of their timeless aesthetics, also the main tenets of scholastic anthropology can tell us something about man.

Now, I will try to show that some forgotten points of medieval thinking can contribute to the study of emotions today.

\section{Solomon's Error}

Robert C. Solomon wrote an important book on The Passions. Emotions and the Meaning of Life. ${ }^{1}$ Published in 1976, the German translation, which came out in 2000, had three editions within one year. Solomon has to be seen as a hero, who in times of great philosophical aridity dared to present the passions as the "key to concrete philosophy" (Solomon 1993, 7). Personally, I like his revival of romanticism, and I share his plea against the separation of the passions from reason (Solomon 1993, 15).

But what about the unity that needs to be achieved between feeling and thinking?

Summing up Solomon's position, I might be somehow unjust, but I am afraid he is missing a central point: When trying to close the gap between the passions and reason, he goes on to say that they are quite the same thing. "The distinction between reason and the passions," Solomon states, "in short, is based upon a series of faulty paradigms... There are no two 'faculties'; there is no distinction” (Solomon 1993, 64).

It may be noticed that Leibniz put it in a similar way: Passion is but a confused perception. ${ }^{2}$

I think, these positions - even if they deserve our sympathy, because they give importance to emotions-are wrong. And what is more: I invite you to examine the medieval thesis about the complementarity of "intellectus" and "affectus"-maybe you will find it more convincing, and better understandable than their alleged unity.

\section{Affectus \& Intellectus: The Medieval Point of View}

When reporting the position of Thomas Aquinas, I think we get to grasp the main tenets of scholastic anthropology. There are differences in the vocabulary which should not disturb us.

The modern tri-partition of the faculties of the human soul into thinking, willing, and feeling was established in the 18th century, which accounts for Kant dedicating his first critique, the "Critique of Pure Reason," to the faculty of thinking, the second critique, the "Critique of Practical Reason," to the faculty of willing, and the third critique, the "Critique of Judgment," to the faculty of feeling.

Well, medieval philosophers differed from this modern tripartition of the soul, supposing that only two faculties would do, namely intellectus and affectus.

As I mentioned, there are shifts in the vocabulary: Affectus sometimes is called also voluntas.

But the main conception is quite clear: There are two faculties of the soul (to be more precise: of the rational soul, because affectus is in the mind).

These faculties form a unity; they interact continuously (as we shall see); so they are by no means separated—but they are clearly distinct. 
Whereas the intellectus helps us to bring the world around us into our consciousness (formally, formaliter, not materially, materialiter - that is the abstractive power of the mind present also in the senses: When seeing a tree, I have it in the mind, but without materia); the affectus (or voluntas) is a complementary faculty.

The latter is harder to describe.

Well, let us first see this complementary faculty as voluntas, will.

It is one thing to leaf through a catalogue of Harrods, and to see all the offers there are.

It is another question altogether if those things please me or not, if I will order them and pay money for having them.

Of course, my "being affected," or my will's decision to have the things from the catalogue, requires some act of awareness. There is no such thing as "blind will" that is a will who wills without knowing what.

The scholastic dictum therefore runs like this: "nil volitum nisi cognitum (nothing can be said to be desired that is not first known)."

Our will refers only to things which somehow are known before.

But to know a thing and to will it are different acts of the soul (or, if you prefer, of the mind). (There might be exceptions-although I would rather speak of coincidence, when Hoelderlin, for instance, says of Diotima that no one can see her without loving her. Seeing and loving remain different acts, even though they here go hand in hand.)

Now, let us see the complementary power of the soul as affectus.

There is a famous question in medieval anthropology: Which of the two main faculties of the soul is the nobler one? When tackling this problem, Thomas Aquinas makes an important distinction: It depends on whether we are referring to things which are below us (e.g., a stone) or above us (e.g., God—but to my understanding, also a human being would do).

Aquinas says: It is better to know a stone than to love it, whereas it is better to love God (and I think, we can add also: It is better to love another human being), than to know him. ${ }^{3}$

It is the great colleague of Thomas Aquinas from the Franciscan Order, St. Bonaventure, who reports the formula of the eminence of affectus over intellectus to us. He uses the metaphor of the soul walking towards the union with God. Of course, it's the whole soul that needs to undertake the way, doing one step by intellectus, and another one by affectus. The last step is done by affectus: "ibi non intrat intellectus, sed affectus (here doesn't enter the intellectus, but the affectus)."

I am afraid that referring to these mystical authors and their seemingly confused terminology may be asking the modern listener a bit much.

However, there is nothing too strange, not even for us. Basically, we know things, and we love (or hate) them. The confusion might come from the claim to explain the functioning of our mind by only two forces, whereby the will and the passions seem to be the same thing.

(On the other hand, it is easy to see that there will never be identity between intellect and will, or between intellect and the passions.)

It was Augustine to show the very simple connection between the will and the passions. The passions are forms or expressions, or transformations of the will: Sadness is our will's reaction if things occur we don't like, and our will is transformed into pleasure when we reach what we want. ${ }^{5}$

Let me give an example. If you would like to go to a concert of your favourite band—for instance "Young Fathers” of Edinburgh—you choose by an act of free will to do so. Assuming that the next day you are queuing 
to get a ticket, there are quite a few people before you and you begin to feel somehow uneasy. Will there be enough tickets? If, alas, the person before you is buying the last ticket, you will, inevitably, feel disappointed (or sad, in any case: You will have negative emotions).

If, in the other case, it’s you to get the last ticket, you will—also inevitably—feel happy (you will have a positive emotion).

Thus, from an act chosen by free will, stems an emotion which, obviously, is far less free; but there is, also obviously, a strong continuity.

To resume: will and emotion, as faculties of the soul, are neighbouring, we could see them as the active and the passive side of the same coin.

Intellect, on the other hand, is a completely different faculty.

Intellect and will, intellectus and affectus, are complementary. They are connected in their function but neatly separated in their essence.

There is no single act of intellect without an act of will (because I have to will the act of my intellect, otherwise no thinking takes place); and there is no single act of will without an act of intellect (because, as we've already seen, I can’t will something completely unknown; thus to know something is the logical condition of willing it).

\section{The Franciscan Discovery of Affectus: Olivi's Contribution}

I hope these few hints have already given an idea of how important the philosophy of emotions was in the Middle Ages. But there is more. Let me draw your attention to a thinker of the Franciscan Order, whose re-discovery began in the 1920's. He turns out to have been one of the most brilliant spirits of his time. Scholars suppose that Dante might have heard his teaching at the convent of Santa Croce in Florence. In the "Dictionnaire des intraduisibles (Dictionary of Untranslatable Terms)," Olivi is said to be a forerunner of the modern theory of subjectivity, which makes us recall Descartes or Kant. ${ }^{6}$

That is true insofar as Olivi stated already that in each act of mind there is an accompanying act of self-consciousness (as Kant stressed): When I am thinking, I know that I am thinking.

This original act of self-consciousness is not given from outside; it comes from the innermost soul. Thus, subjectivity is the ground of objectivity.

So was Olivi a predecessor of Descartes or Kant? It seems so, but he had a theory of subjectivity of his own. Unfortunately, Olivi did not have much impact on the history of philosophy, because his works were forbidden. Whereas he was venerated nearly like a saint until the beginning of the 14th century, in 1323, Pope John XXII decided that Thomas Aquinas should be canonized and that Olivi should be forgotten.

Descartes thought that even when we are overwhelmed by doubt about everything, there still remains one certainty which is not doubtable: Namely that I, who am doubting, exist. But Olivi sees another problem: It can be accepted that there is something which doubts, and that this doubting thing exists. But who tells you that the existing doubting thing is you? Who guarantees the link between the doubting thing and me? (It seems to me that Descartes didn't have any problem with this link.) To put it in other words: who guarantees that the attribution of the first person to the thinking thing is justified?

Olivi has seen this point. Descartes arrests his doubt when stating: I think, therefore I am. Olivi goes further: The root of self-consciousness is not in the intellectual, but in the affective power of the soul-because the certainty of an existing thinking thing doesn't reach the first-person perspective. ${ }^{7}$ The ground of objectivity 
is subjectivity, but what is the core of subjectivity?

It's thinking, says Descartes. It's feeling, says Olivi. It's not thinking that allows me to identify my thoughts as my thoughts. The ground of subjectivity doesn't lie in intellectus, but in affectus. Subjectivity is, ultimately, affectivity.

I think, therefore I am—and I feel, therefore I am I.

Olivi didn't express himself in such an anti-cartesian way ante litteram, nor did he speak in terms of "first-person perspective.” But what he wants to say is quite clear.

In one of his most famous questions which is dedicated to the problem of freedom (at the end of the 13th century that was a big question, already), he presents a phenomenologically well founded theory of human emotions. There are seven couples of emotions, as anger and compassion, friendship and hostility, glory and shame, gratitude and ingratitude, and so on. These emotions, the argument runs, make sense only if there is freedom. The emotions are signs, or to put it stronger, forms of freedom.

Later on, free will is examined as the power of love. The "potestas amativa (power to love)" (Olivi 2006, 86) is the highest power of the soul. Will has also the "primacy in existence.” It's our will which strives for eternity, and it is our heart which infinitely exceeds every other kind of existence ("sentimus cor nostrum quasi in infinitum excedere omnem alium modum existendi”) (Olivi 2006, 94).

In Olivi, there is a clear shift from intellect to will: Reflexivity as well as freedom is mainly in the affectus. Olivi speaks of the "substantialis claritas intellectus (substantial clarity of the intellectus)," and of the "substantialis libertas affectus (substantial freedom of the affectus).",

All philosophical ideas are counter-ideas. The Franciscan discovery of free will and affectivity is directed against the intellectualism of Aquinas (who followed Aristotle), and-if you allow me the anachronism—against the rationalism of Descartes, Kant, and the philosophical main streaming up to now.

\section{Lenina and the Savage}

Let's go back to Brave New World. One of the deepest emotions-even, without doubt, the deepest of all—was, and is still supposed to be, love.

Remember the love scene between Lenina and the Savage in chapter XIII of Huxley's book. Lenina and the Savage have fallen in love with one another, know it, and even confess it. So, what is it that doesn't work between them?

Lenina, an "uncommonly pretty” girl, ${ }^{9}$ ready to have sex with the Savage, is pushed away. "Whore," he calls her, quoting endlessly odd Shakespearian texts.

The drama is: Both are in love, and love means-as Olivi would tell us when speaking about friendship (Olivi 2006, 60/62) — to make the gift of oneself (more precisely: the gift of one's self) to another self. That's the definition of friendship. But, as Olivi reminds us, in order to give away myself (my self) to the beloved person — to my friend—first I must possess myself. And this is the point of which Lenina, in the spoiled love scene with the Savage, isn't aware: She has no self.

Of course, Lenina feels something for the Savage, and wants him, but he, who obviously wants her, too, asks for more. Sexual desire is not the deepest emotion-love is.

Selfless sex is what happens in Huxley's Brave New World, and its habitants, even Alphas like Lenina, don't know better. 
Only a strong "I” can get into a relation with a “Thou;” but in Huxley's world there is no such thing as a strong I.

And therefore, no strong relationship, no real love.

\section{7. "Scientia Affectiva"}

I am coming to the end. There is a beautiful notion in medieval theory of science which may sound strange to modern ears: the notion of the so-called "scientia affectiva."

What should that be, "scientia affectiva”? Isn't it a bare "contradictio in adiecto (contradiction in terms)" to combine such disparate things like "science" and "affectivity" within one concept?

We may think of the "affective sciences" which have been receiving increasing attention in the last years. Affective sciences are, if I am right, a part of neuro-science which studies the physiology of emotions: What is going on in the brain when we feel happy or angry.

The medieval term "scientia affectiva" means another thing.

When the great scholastics of the 13th century wrote their theological summas, first of all they had to clarify which sort of science theology was.

And there could be three answers.

Theology could be a "scientia speculativa;" that means: a science which addresses itself to the human intellect and perfects our knowledge (that is, for instance, the position of Aquinas).

Theology could also be seen as a "scientia practica;" that means: a science which addresses itself to human action and perfects it (that is, for instance, the position of Duns Scotus, one of the greatest medieval philosophers, born in Duns, about 50 miles southeast of Edinburgh).

Theology could, at last, be seen also as a "scientia affectiva.” What does that mean?

I suggest: It means a science which addresses itself to our affective forces and perfects them.

One of the supporters of this position-Ulrich of Strasburg, a disciple of Albertus Magnus, explains himself as follows (I partly am paraphrasing and partly quoting): The object of theology is God. He is the highest good and the ultimate goal of everything. But he is not known adequately by pure speculation without affection. Because nobody is able to know perfectly a good which is not loved... Therefore it is clear that the goal of this science is an affective knowledge ("notitia affectiva").

This knowledge includes three things: a speculative knowledge, because we cannot love the unknown...; and love... and, thirdly, a work agreeable to the beloved one. Because this love is the reason why in Scripture it says about those who have a notion of God without love and without good work, that they don’t know God... ${ }^{10}$

Ulrich of Strasburg understands theology as "scientia affectiva," because the affective moment integrates the speculative and the practical one.

It is therefore clear that from this point of view, affectivity is the most integrating power of the soul; and "scientia affectiva" the most integrating science.

I am not sure if there are actually theologians, or philosophers, who would dare to characterize their science as an "affective” one. Perhaps they would prefer not to do so, because it might sound very unscientific.

But for those interested in the study of emotions, "scientia affectiva" certainly could be worth discussing. 


\section{Notes}

1. Robert C. Solomon, The Passions. Emotions and the Meaning of Life (Indianapolis: Hackett, 1993; first published in 1976).

2. Solomon, loc. cit., 87; Leibniz, Monadology, § 49. Since the monads of Leibniz are endowed with perceptions and appetitions, I find it hard to think of Leibniz as confusing those two qualities. But that is not our problem here.

3. Thomas Aquinas, Summa theol., I, qu. 82, art. 3.

4. Bonaventura, Collationes in Hexaemeron, II, 32, Opera omnia, Vol. V, 342 a.

5. Augustine, The City of God (De civitate dei), XIV, 6.

6. Alain de Libera, “sujet,” Barbara Cassin (ed.), Vocabulaire européen des philosophies. Dictionnaire des intraduisibles, Paris, 2004, 1240.

7. "Impugnatio quorundam articulorum Arnaldi Galliardi," art. 19: Here Olivi denies the position that every cognition is generated "mediante fantasmate et cum successione et tempore (by means of a phantasma, and with succession and time)," (loc. cit., nr. 1). However, the "certitudo infallibilis sui esse (the infallible certainty of one’s own existence)," (ivi, nr. 10) is immediate. Otherwise, Olivi argues, if we had to conclude the certainty of our own existence from our acts (as Descartes, 350 years later, will do), we would lack the certainty that these acts are ours: "Licet enim certi simus quod illi actus manant ab aliqua potentia et sunt in aliquo subiecto, unde per hoc sciemus quod illud subiectum sumus nos et quod illa potentia est nostra (Even if we are sure that those acts stem from some potency and are in some subject, how should we know therefrom that we are that subject and that that potency is ours)?" (Ivi.) The "impugnatio (contestation)" is quoted from http://oliviana.revues.org/56.

8. Olivi, Quaestiones in II Sententiarum, Vol. III, qu. 79; ed. B. Jansen, Quaracchi, 1926, 161.

9. Huxley (note 1), 13.

10. Ulrich of Strasburg, De summo bono, liber 1, tract. 2, cap. 4; ed. by B. Mojsisch (Hamburg, Meiner: 1989, 37). Peter Nickl, Philosophie als "scientia affectiva"? Ein mittelalterlicher Begriff und seine Spuren in der Neuzeit, Perspektiven der Philosophie. Neues Jahrbuch, 31 (2005): 47-70.

\section{Works Cited}

Huxley, Aldous. Brave New World. London: Flamingo, 1994.

Olivi, Quaestio an in homine sit liberum arbitrium (Question If There Is Free Will in Man). Freiburg i.Br.: Herder, 2006. (=Herders Bibliothek der Philosophie des Mittelalters, Vol. 8.)

Solomon, Robert. The Passions. Emotions and the Meaning of Life. Indianapolis: Hackett, 1993; first published in 1976. 